\title{
Rice Yield and Available Nutrients Status of Loamy Sand Soil as Influenced by Different Levels of Silicon and Nitrogen
}

\author{
J.K. Malav ${ }^{1 *}$, V.P. Ramani ${ }^{2}$, J.K. Patel ${ }^{1}$, R.P. Pavaya ${ }^{1}$, B.B. Patel ${ }^{1}$, \\ I.M. Patel ${ }^{3}$ and V.R. Patel ${ }^{1}$
}

${ }^{I}$ Department of Agricultural Chemistry and Soil Science, C.P. College of Agriculture, S.D. Agricultural University, Sardarkrushinagar-385 506 (Gujarat), India

${ }^{2}$ Micronutrient Research Project (ICAR), Anand Agricultural University, Anand-388001, Gujarat, India

${ }^{3}$ Cental Instrumentation Laboratory, S.D. Agricultural University, Sardarkrushinagar-385 506 (Gujarat), India

*Corresponding author

\section{A B S T R A C T}

\begin{tabular}{|c|}
\hline Keywords \\
\hline $\begin{array}{l}\text { Nutrients, Loamy } \\
\text { sand soil, Silicon, } \\
\text { Nitrogen }\end{array}$ \\
\hline Article Info \\
\hline $\begin{array}{l}\text { Accepted: } \\
\text { 07 January } 2018 \\
\text { Available Online } \\
10 \text { February } 2018\end{array}$ \\
\hline
\end{tabular}

A field trial was conducted during kharif seasons of 2014 and 2015 on loamy sand, at the Agriculture Research Station, Anand Agricultural University, Jabugam, Gujarat (India), to assess the available nutrient status after harvest of rice soil as influenced by different levels of silicon and nitrogen application under loamy sand. The experiment encompassed four levels of nitrogen viz., $0,75,100$ and $125 \mathrm{~kg} \mathrm{~N} \mathrm{ha}^{-1}$ from ammonium sulphate and four levels of silicon viz., 0, 200, 400 and $600 \mathrm{~kg} \mathrm{Si} \mathrm{ha}^{-1}$ from calcium silicate. The experiment was laid out in randomized block design (Factorial) with three replications. Results revealed that individual application of nitrogen@125 kg ha ${ }^{-1}$ and $\mathrm{Si} @ 600 \mathrm{~kg} \mathrm{ha}^{-1}$ produced the highest grain and straw yields of rice. The salt content, $\mathrm{pH}$ and organic carbon content of soil remained almost unchanged due to $\mathrm{N}$ and/ or $\mathrm{Si}$ applications. The available $\mathrm{N}$ content in soil was found to increase with graded levels of $\mathrm{N}$ and $\mathrm{Si}$ application. Similarly, available Si content in soil was also increased due to $\mathrm{Si}$ as well as N application. Application of $600 \mathrm{~kg} \mathrm{Si} \mathrm{ha}^{-1}$ significantly increased the $\mathrm{P}, \mathrm{K}$ and $\mathrm{S}$ contents in soil after harvest of rice. The effect of $\mathrm{N}$ on available $\mathrm{K}_{2} \mathrm{O}$ content in soil after harvest of the crop was significantly increased.

\section{Introduction}

Silicon ( $\mathrm{Si}$ ) is one of the most abundant elements found in the earth's crust, but is mostly inert and only slightly soluble. Agriculture activity tends to remove large quantities of $\mathrm{Si}$ from the soil. Rice is known to absorb more Si than any other mineral nutrient accumulates in the plant. Response to silicon fertilization has been documented in some areas of the world. The reason for this plant response or yield increase is not fully understood, but several mechanisms have been proposed. Plant growth studies indicate that rice yield responses to silicon may be associated with induced resistance to biotic 
and abiotic stresses such as disease and pest resistance, $\mathrm{Al}, \mathrm{Mn}$ and Fe toxicity alleviation, increased $\mathrm{P}$ availability, reduced lodging, improved leaf and stalk erectness, freeze resistance, and improvement in plant water economy. This review covers the relationship of silicon to rice crop production, including recommendations on how to manage silicon in soils and plants and silicon interactions with other elements in a best manner.

Rice is considered to be a Si accumulator plant and tends to actively accumulate Si to tissue concentrations of 5 per cent or higher (Epstein, 1999). Application of $\mathrm{N}$ fertilizers is an important practice for increasing rice yields. However, when applied in excess may limit, yield because of lodging, promote shading and susceptibility to insects and diseases. These effects could be minimized by the use of Si (Munir et al., 2003). Information on the importance of $\mathrm{Si}$ in Indian rice farming system is limited (Prakash, 2002). Rice is prone to various stresses if the available soil silicon is low for absorption. Production of $5 \mathrm{t}$ $\mathrm{ha}^{-1}$ of grain yield of rice is estimated to remove about 230-470 kg elemental Si from soil, depending upon soil and plant factors. Absorption will be about $108 \%$ more than the $\mathrm{N}$ content. Adequate supply of silicon of rice from tillering to elongation stage increases the number of grains panicle ${ }^{-1}$ and the percentage of ripening (Korndorfer et al., 2001). Silicon has been reported to raise the optimal level of nitrogen in rice.

Silicon plays an important role in balancing nutrient absorption (Ma et al., 2006). Its absorption and transport, $\mathrm{Si}$ often interacts with other elements. In an agricultural context, those interactions in which $\mathrm{Si}$ interferes with absorption or partitioning of nutrients at concentrations high enough to be damaging to the plants, are particularly noteworthy. Toxicities of $\mathrm{Al}$ and other metal ions common in highly leached, acidic, and decalcified soils, are often mitigated by $\mathrm{Si}$, and experimental work with solution cultures has shown the same effect. Si may retard or minimize $\mathrm{Na}$ uptake by plants, thereby reducing the potential damage caused due to salinity. Silicon may enhance soil fertility, improve disease and pest resistance, increase photosynthesis, improve plant architecture, regulate transpiration, increase tolerance to the toxicity of the elements such as Fe and $\mathrm{Mn}$, and reduce frost damage. Silicon promotes plant health (Muir et al., 2001) and soil productivity. Both agronomists and horticulturists use $\mathrm{Si}$; as a fertilizer for crop on certain soil and reported that its use increases yields and sometimes act as a quality-key factor in crop production. Silicon is involved in a great number of structural and dynamic aspects of plant life, and its rules are surprisingly diverse. Therefore, the paper deals with available nutrients status after harvest of rice soils in influenced by different levels of silicon and nitrogen application under loamy sand.

\section{Materials and Methods}

In order to achieve the pre-set objectives of the present investigation, a field experiment was conducted during the Kharif season for two years 2014 and 2015 at Agricultural Research Station, Anand Agricultural University, Jabugam, Gujarat. Geographically, Jabugam is situated at $22^{0} 17^{\prime} 37.70^{\prime \prime}$ north latitude, $73^{\circ} 46^{\prime} 41.02$ " east longitude with an elevation of 92 meters above mean sea level. The climate of Jabugam region is semi-arid and sub-tropical with hot summer and cold winter. In this region, generally monsoon commences in the month of June and retreats from the end of September. Most of the rainfall is received from south-west monsoon currents. July and August are the months of heavy showers. The total rainfall of the region is about $800-1000 \mathrm{~mm}$. Average minimum and maximum temperature of both the year of 
study was $19.6^{\circ} \mathrm{C}$ and $33.3^{\circ} \mathrm{C}$, respectively. The soil was loamy sand, with a sand, fine sand, silt and clay composition of 49.85, 26.6, 10.0 and $12.1 \%$, respectively.

To assess the fertility status of soil, representative composite soil samples from each net plot area was collected after harvesting of the crop. Soil samples were thoroughly mixed and air-dried. Soil was ground using wooden mortar and pestle and then passed through $2 \mathrm{~mm}$ plastic sieve to avoid metallic contamination. The processed soil samples were analyzed for soil physical and chemical properties by adopting standard methods given in Table 1.

The experiment was based on a Randomized Block Design with factorial concept encompassing three replications and sixteen combined treatments. The plot size was $5.0 \mathrm{~m}$ $\times 3.6 \mathrm{~m}$ and the total numbers of unit plots were $48(16 \times 3)$, GAR 13 (Gujarat Anand Rice 13) variety was used in this experiment. The entire dose of phosphorus as per recommendation was applied through single super phosphate. Four levels (0, 75, 100 and $125 \mathrm{~kg} \mathrm{ha}^{-1}$ ) of $\mathrm{N}$ were applied through ammonium sulphate in 3 equal splits $(1 / 3$ basal, $1 / 3$ at active tillering stage and $1 / 3$ at panicle initiation stage) and four levels (0, 200, 400 and $600 \mathrm{~kg} \mathrm{ha}^{-1}$ ) of Si were applied through calcium silicate at the time of sowing.

\section{Results and Discussion}

\section{Grain and straw yield}

Data in Table 2 illustrated that application of nitrogen had a significant effect on grain yield of rice. The lowest grain $\left(5241 \mathrm{~kg} \mathrm{ha}^{-1}\right)$ and straw (6961 kg ha ${ }^{-1}$ ) yield was observed under control and maximum grain (6445 $\mathrm{kg} \mathrm{ha}^{-1}$ ) and straw $\left(8658 \mathrm{~kg} \mathrm{ha}^{-1}\right)$ yields was recorded due to application of $125 \mathrm{~kg} \mathrm{~N}^{-1}$. The treatment $125 \mathrm{~kg} \mathrm{~N} \mathrm{ha}^{-1}$ gave a significantly higher grain yield over the control. The increase in yield as a result of nitrogen application could be due to the marginal nitrogen content of soil, improvement in root development and vegetative growth as well. The improvement in yield attributing traits may be ascribed to the improved vegetative growth due to $\mathrm{N}$ fertilization, facilitating photosynthesis, thereby increasing translocation of organic food materials towards the reproductive organs; which enhanced the formation of panicles with fertile grains. The results are in conformity with those of Mahajan and Tripathi (1992), Dehal and Mishra (1994).

Sudhakar et al., (2006) also observed 16.7 per cent increase in grain yield with application of $\mathrm{N}$ at $160 \mathrm{~kg} \mathrm{ha}^{-1}$ as compared to $80 \mathrm{~kg} \mathrm{~N} \mathrm{ha}^{-1}$. Above all, excess $\mathrm{N}$ also prolongs the vegetative growth at the cost of reproductive growth, thus, diminishing the production of carbohydrates (Mauad et al., 2003). Singh et al., (2002) reported that the grain yield increased significantly due to $120 \mathrm{~kg} \mathrm{~N}^{-1}$ contributing in three times (transplanting time, tillering time and panicle initiation).

The results presented in Table 2 illustrate that the rice grain and straw yield was significantly influenced by silicon application. The significantly higher grain $\left(6163 \mathrm{~kg} \mathrm{ha}^{-1}\right)$ and straw $\left(8536 \mathrm{~kg} \mathrm{ha}^{-1}\right)$ yield per plot was recorded due to silicon application at $600 \mathrm{~kg}$ $\mathrm{ha}^{-1}$; while the lowest grain $\left(5693 \mathrm{~kg} \mathrm{ha}^{-1}\right)$ and straw (7319 kg ha $\mathrm{kg}^{-1}$ yield per plot was recorded under control. The treatment $600 \mathrm{~kg}$ $\mathrm{Si} \mathrm{ha}{ }^{-1}$ gave significantly higher grain and straw yields over the control and $200 \mathrm{~kg} \mathrm{Si} \mathrm{ha}^{-}$ ${ }^{1}$; which was at par with $400 \mathrm{~kg} \mathrm{Si} \mathrm{ha}{ }^{-1}$. The increase in rice yield might be due to increased availability of silicon. The lower yield in the control compared to silicon fertilized plots, might be due to leaching and fixation loss of native silicon in submerged conditions which is inadequate in meeting the $\mathrm{Si}$ requirement by the crop for producing 
higher grain yield. The increase in yield with $\mathrm{Si}$ application could be due to beneficial effects viz., decreasing mutual shading by improving leaf erectness, decreasing susceptibility to lodging, decreasing the incidence of infections with root parasites and pathogens, leaf pathogens and preventing manganese and iron toxicity or both. Increased water use efficiency observed with the application of $\mathrm{Si}$, probably might be due to prevention of excessive transpiration. During the reproductive stage, silicon is preferentially transported into the flag leaves, and interruption of silicon supply at this stage is detrimental for spikelet fertility (Ma et al., 2006). The results are in line with the findings of Savant et al., (1997). Chen et al., (2011) stated that the silicon application increased grain yield by increase of spikelet number, filled spikelet percentage and 1000-seed weight. Mauod et al., (2003) and Ma and Takahashi, (1990) reported that grain yield increased by silicon application. The interaction effect between $\mathrm{N}$ and $\mathrm{Si}$ on a grain and straw yields of rice was non-significant.

\section{Effect of $\mathrm{N}$ and $\mathrm{Si}$ on chemical properties of soil after harvest of rice}

At the harvest of the crop, some of the soil physico-chemical and chemical parameters viz., $\mathrm{pH}, \mathrm{EC}, \mathrm{OC}$, available $\mathrm{N}, \mathrm{P}_{2} \mathrm{O}_{5}, \mathrm{~K}_{2} \mathrm{O}, \mathrm{S}$ and $\mathrm{Si}$ were studied to observe the influence of different $\mathrm{N}$ and Si levels on the soil properties with rice crop. The results pertaining to the soil parameters are presented in Table 2 to 4 .

\section{pH, electrical conductivity and organic carbon}

The data Table 2 revealed that individual effect of $\mathrm{N}$ and $\mathrm{Si}$ and also their interaction found to be non-significant for organic carbon, electrical conductivity $\left(\mathrm{dS} \mathrm{m}{ }^{-1}\right)$ and soil $\mathrm{pH}$ after harvest of rice during both individual years as well as on a pooled basis.

\section{Available nitrogen $\left(\mathrm{kg} \mathrm{ha}^{-1}\right)$}

The data presented in Table 3 indicated that varying levels of $\mathrm{N}$ significantly influenced the available nitrogen in soil after harvest of rice. The lowest available nitrogen content after harvest of crop $(255,231$ and $243 \mathrm{~kg}$ $\mathrm{ha}^{-1}$ ) was observed under control during both individual years as well as on a pooled basis. The maximum available nitrogen content (324, 308 and $\left.316 \mathrm{~kg} \mathrm{ha}^{-1}\right)$ was recorded due to application of $125 \mathrm{~kg} \mathrm{~N}^{-1}$ during both individual years as well as on a pooled basis. The treatment $125 \mathrm{~kg} \mathrm{~N} \mathrm{ha}{ }^{-1}$ registered significantly higher available nitrogen over the control and $75 \mathrm{~kg} \mathrm{~N} \mathrm{ha}^{-1}$ during both individual years as well as on a pooled basis. However, it was at par with $100 \mathrm{~kg} \mathrm{~N} \mathrm{ha}^{-1}$ during the first year only. The highest improvement over control was to the tune of 27, 34 and 30 per cent during both individual years as well as on a pooled basis, respectively. When compared to the initial status, there was 29 percent depletion in the control and 24 percent built up in available status at $\mathrm{N}_{125}$ fertility level. It could also be observed that with increase in $\mathrm{N}$ levels, the nutrient contents also increased accordingly.

Data in Table 3 illustrated that application of silicon had a significant effect on available nitrogen in soil after harvest of crop during both individual years and as well as on a pooled basis. The lowest available nitrogen content in soil after harvest of rice crop (258, 237 and $248 \mathrm{~kg} \mathrm{ha}^{-1}$ ) was observed under control during both the years as well as on a pooled basis. The maximum available nitrogen content in soil $\left(320,309\right.$ and $\left.315 \mathrm{~kg} \mathrm{ha}^{-1}\right)$ was recorded due to application of $600 \mathrm{~kg} \mathrm{Si} \mathrm{ha}{ }^{-1}$ during both individual years as well as on a pooled basis. The treatment $600 \mathrm{~kg} \mathrm{Si} \mathrm{ha}{ }^{-1}$ gave significantly higher available nitrogen content in soil after harvest of crop over the control and $200 \mathrm{~kg} \mathrm{Si} \mathrm{ha}{ }^{-1}$ during both the years as well as on a pooled basis. However, it 
was at par with $400 \mathrm{~kg} \mathrm{Si} \mathrm{ha}^{-1}$ during first year only. The greatest improvement was to the tune of 24, 30 and 27 per cent during both individual years as well as on a pooled basis respectively, over control. When compared to the initial status, there was 26 percent depletion in the control and 23 percent built up in available status at $\mathrm{Si}_{600}$ fertility level. It could also be observed that, with increase in $\mathrm{N}$ levels, the nutrient contents also increased accordingly. The improved nitrogen status in soil by the use of $\mathrm{N}$ and $\mathrm{Si}$ fertilization can be explained by high adsorption capacity of $\mathrm{Si}$ and increased microbial activity, which might have hastened the process of mineralization during crop growth period resulting in high accumulation of $\mathrm{N}$ in soil in the Si treated soil (Biel et al., 2008).

The data on the interaction effect of $\mathrm{N} \times \mathrm{Si}$ (Table 4) revealed that significantly highest $\mathrm{N}$ content in soil after harvest of crop was observed due to combined effect of $125 \mathrm{~kg} \mathrm{~N}$ $\mathrm{ha}^{-1}$ and $600 \mathrm{~kg} \mathrm{Si} \mathrm{ha}{ }^{-1}$ application $(386 \mathrm{~kg}$ $\mathrm{ha}^{-1}$ ) over rest of the combinations. The lowest $\mathrm{N}$ content in soil after harvest of crop was noticed in control plots $\left(226 \mathrm{~kg} \mathrm{ha}^{-1}\right)$. It could also be observed that, with increase in $\mathrm{N}$ levels, the nutrient contents also increased accordingly.

The improved nitrogen status in soil by the use of $\mathrm{N}$ and $\mathrm{Si}$ fertilization can be explained by high adsorption capacity of $\mathrm{Si}$ and increased microbial activity, which might have hastened the process of mineralization during crop growth period resulting in high accumulation of $\mathrm{N}$ in soil in the $\mathrm{Si}$ treated soil (Biel et al., 2008). The improved nitrogen status in soil by the use of $\mathrm{N}$ fertilization can be explained by high adsorption capacity of $\mathrm{N}$ and increased microbial activity, which might have hastened the process of mineralization during crop growth period resulting in high accumulation of $\mathrm{N}$ in soil in the $\mathrm{N}$ treated soil (Biel et al., 2008). Matichenkov et al., 2000 reported similar results in commercial fields of Mossman to Bundaberg. These results are in accordance with the findings of Snyder et al., (1986) and Malidareh et al., (2009).

\section{Available silicon $\left(\mathrm{kg} \mathrm{ha}^{-1}\right)$}

A perusal of data presented in Table 3 revealed that application of $\mathrm{N}$ increased the $\mathrm{Si}$ content in soil after harvest of rice crop during both individual years as well as on a pooled basis. The lowermost silicon content (199.6, 214.7 and $207.2 \mathrm{~kg} \mathrm{ha}^{-1}$ ) was observed under control during both the years as well as on a pooled basis. The maximum silicon content in soil after harvest of rice crop (241.0, 258.1 and $249.6 \mathrm{~kg} \mathrm{ha}^{-1}$ ) was recorded due to application of $125 \mathrm{~kg} \mathrm{~N} \mathrm{ha}{ }^{-1}$ during both individual years as well as on a pooled basis, respectively. The treatment $125 \mathrm{~kg} \mathrm{~N}^{-1}$ gave significantly higher $\mathrm{Si}$ content in soil after harvest of crop over the control and $75 \mathrm{~kg} \mathrm{~N}$ $\mathrm{ha}^{-1}$ during both the years as well as on a pooled basis. However, it was at par with 100 $\mathrm{kg} \mathrm{N} \mathrm{ha}{ }^{-1}$ during both the years as well as pooled basis. The furthermost improvement over control was to the assessment of 21,20 and 20 per cent during both individual years as well as on a pooled basis, respectively.

There was an increase up to an extent of 26 per cent in available $\mathrm{Si}$ content of the soil when compared to the initial status even without its fertilization. This could be due to the reason that $\mathrm{Si}$ is released into the soil solution after flooding as well as with organic matter content of soil as reported earlier by Ponnamperuma (1972). The highest Si status by submerged may be due to reduction of silicon by hydrous oxide of $\mathrm{Fe}^{3+}$ sorbing occluded silicon and the action of carbon dioxide on aluminosilicates (Ponnamperuma 1972 and Nayar et al., 1982). The application of $\mathrm{N}$ fertilizers showed greater accumulation of $\mathrm{Si}$ in soil. The results are in agreement with the findings of Inanaga et al., (2002). 
Table.1 Initial physico-chemical properties of the experimental soil

\begin{tabular}{|c|c|c|c|c|c|}
\hline $\begin{array}{l}\text { Sr. } \\
\text { No. }\end{array}$ & Determination & 2014 & 2015 & Method & Reference \\
\hline $\mathbf{A}$ & \multicolumn{5}{|l|}{ Physical Properties } \\
\hline \multirow[t]{6}{*}{1} & \multicolumn{3}{|c|}{ Particle size distribution $\left(\mathrm{g} 100 \mathrm{~g}^{-1}\right)$} & \multirow{6}{*}{$\begin{array}{l}\text { International pipette } \\
\text { method }\end{array}$} & \multirow[t]{6}{*}{ Piper (1966) } \\
\hline & Coarse Sand & 49.85 & 49.80 & & \\
\hline & Fine sand & 26.6 & 26.70 & & \\
\hline & Silt & 10.0 & 10.0 & & \\
\hline & Clay & 13.55 & 13.50 & & \\
\hline & Texture & $\begin{array}{l}\text { Loamy } \\
\text { sand }\end{array}$ & $\begin{array}{l}\text { Loamy } \\
\text { sand }\end{array}$ & & \\
\hline 2 & Bulk density $\left(\mathrm{Mg} \mathrm{m}^{-3}\right)$ & 1.38 & 1.26 & $\begin{array}{l}\text { Cylindrical core } \\
\text { method }\end{array}$ & Jackson (1973) \\
\hline 3. & 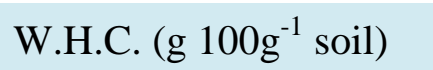 & 38.89 & 37.37 & Brass Cup Method & Jackson (1973) \\
\hline B & \multicolumn{5}{|c|}{ Physico-Chemical Properties } \\
\hline 1 & $\mathrm{pH}(1: 2.5)$ & 6.32 & 6.13 & Potentiometry & Jackson (1973) \\
\hline 2 & $\mathrm{EC}(1: 2.5) \mathrm{dSm}^{-1}$ & 0.43 & 0.38 & Conductometry & Jackson (1973) \\
\hline 3 & Organic carbon $\left(\mathrm{g} \mathrm{kg}^{-1}\right)$ & 6.10 & 5.50 & $\begin{array}{l}\text { Modified Walkley } \\
\text { and Black method }\end{array}$ & $\begin{array}{l}\text { Walkley and } \\
\text { Black (1934) }\end{array}$ \\
\hline $\mathbf{C}$ & \multicolumn{5}{|l|}{ Chemical Properties } \\
\hline 1 & Available $\mathrm{N}\left(\mathrm{kg} \mathrm{ha}^{-1}\right)$ & 313 & 310 & $\begin{array}{l}\text { Alkaline } \mathrm{KMnO}_{4} \\
\text { method }\end{array}$ & $\begin{array}{l}\text { Subbiah and } \\
\text { Asija (1956) }\end{array}$ \\
\hline 2 & Available $\mathrm{P}_{2} \mathrm{O}_{5}\left(\mathrm{~kg} \mathrm{ha}^{-1}\right)$ & 88 & 90 & $\begin{array}{l}\text { Olsen's method ( } 0.5 \\
\mathrm{M} \mathrm{NaHCO}_{3}, \mathrm{pH} 8.5\end{array}$ & $\begin{array}{l}\text { Olsen et al., } \\
\text { (1954) }\end{array}$ \\
\hline 3 & $\begin{array}{l}\text { Available } \mathrm{K}_{2} \mathrm{O} \\
\left(\mathrm{kg} \mathrm{ha}^{-1}\right)\end{array}$ & 221 & 205 & $\begin{array}{l}\text { Neutral } \mathrm{N} \mathrm{NH}_{4} \mathrm{OAc} \\
\text { Flame photometry } \\
\text { method }\end{array}$ & Jackson (1973) \\
\hline 4 & Available S ( $\left.\mathrm{mg} \mathrm{kg}^{-1}\right)$ & 3.53 & 3.98 & $\begin{array}{l}\text { Turbidimetric } \\
\text { method }(0.15 \% \\
\left.\mathrm{CaCl}_{2}\right)\end{array}$ & $\begin{array}{l}\text { Williams and } \\
\text { Steinbergs } \\
\text { (1959) }\end{array}$ \\
\hline 5 & Available Si $\left(\mathrm{kg} \mathrm{ha}^{-1}\right)$ & 190.8 & 185.0 & $\begin{array}{l}\mathrm{NaOAc}(\mathrm{pH}-4) \\
\text { Colorimetric method }\end{array}$ & $\begin{array}{l}\text { Korndorfer } \\
\text { et al., (1999) }\end{array}$ \\
\hline
\end{tabular}


Table.2 Effect of $\mathrm{N}$ and $\mathrm{Si}$ on yield, $\mathrm{pH}, \mathrm{EC}$ and $\mathrm{OC}$ contents after harvest of rice under low land conditions (pooled 2 years)

\begin{tabular}{|c|c|c|c|c|c|c|c|c|c|c|c|c|c|}
\hline \multirow{2}{*}{\multicolumn{2}{|c|}{ Treatments }} & \multicolumn{3}{|c|}{ Yield $\left(\mathrm{kg} \mathrm{ha}^{-1}\right)$} & \multicolumn{3}{|c|}{ pH } & \multicolumn{3}{|c|}{$\mathrm{EC}\left(\mathrm{dSm}^{-1}\right)$} & \multicolumn{3}{|c|}{$\mathrm{OC}\left(\mathrm{g} \mathrm{kg}^{-1}\right)$} \\
\hline & & 2014 & 2015 & Pooled & 2014 & 2015 & Pooled & 2014 & 2015 & Pooled & 2014 & 2015 & Pooled \\
\hline \multicolumn{14}{|c|}{ Nitrogen levels $\left(\mathrm{kg} \mathrm{ha}^{-1}\right)$} \\
\hline \multicolumn{2}{|l|}{ N 0} & 5316 & 5166 & 5241 & 6.82 & 6.75 & 6.79 & 0.24 & 0.27 & 0.25 & 3.48 & 3.65 & 3.57 \\
\hline \multicolumn{2}{|l|}{ N 75} & 5910 & 6171 & 6040 & 7.19 & 6.80 & 6.99 & 0.24 & 0.25 & 0.24 & 3.82 & 3.91 & 3.86 \\
\hline \multicolumn{2}{|l|}{$\mathbf{N} 100$} & 6023 & 6304 & 6163 & 6.68 & 7.02 & 6.85 & 0.22 & 0.25 & 0.23 & 3.94 & 4.10 & 4.02 \\
\hline \multicolumn{2}{|l|}{$\mathbf{N} 125$} & 6405 & 6486 & 6445 & 6.84 & 7.11 & 6.98 & 0.25 & 0.27 & 0.26 & 4.03 & 4.21 & 4.12 \\
\hline \multirow[t]{2}{*}{$\mathbf{N}$} & S. Em \pm & 113 & 109 & 78 & 0.17 & 0.20 & 0.13 & 0.01 & 0.01 & 0.01 & 0.16 & 0.17 & 0.12 \\
\hline & $\mathrm{CD}(0.05)$ & 325 & 314 & 221 & NS & NS & NS & NS & NS & NS & NS & NS & NS \\
\hline \multirow[t]{2}{*}{$\mathbf{Y} \mathbf{x} \mathbf{N}$} & S. Em \pm & 111 & 111 & 111 & 0.19 & 0.19 & 0.19 & 0.01 & 0.01 & 0.01 & 0.16 & 0.16 & 0.16 \\
\hline & $\mathrm{CD}(0.05)$ & - & - & NS & - & - & NS & - & - & NS & - & - & NS \\
\hline \multicolumn{14}{|c|}{ Silicon levels $\left(\mathrm{kg} \mathrm{ha}^{-1}\right)$} \\
\hline \multicolumn{2}{|c|}{ Si 0} & 5570 & 5816 & 5693 & 6.58 & 6.88 & 6.73 & 0.22 & 0.25 & 0.24 & 3.59 & 4.15 & 3.87 \\
\hline \multicolumn{2}{|l|}{ Si 200} & 5951 & 5936 & 5944 & 6.75 & 7.07 & 6.91 & 0.23 & 0.27 & 0.25 & 3.77 & 3.85 & 3.81 \\
\hline \multicolumn{2}{|l|}{ Si 400} & 6030 & 6151 & 6091 & 6.99 & 6.86 & 6.93 & 0.24 & 0.24 & 0.24 & 3.92 & 4.09 & 4.00 \\
\hline \multicolumn{2}{|l|}{ Si 600} & 6102 & 6224 & 6163 & 7.20 & 6.87 & 7.03 & 0.23 & 0.27 & 0.25 & 3.99 & 3.77 & 3.88 \\
\hline \multirow[t]{2}{*}{ Si } & S. Em \pm & 113 & 109 & 78 & 0.17 & 0.20 & 0.13 & 0.01 & 0.01 & 0.01 & 0.16 & 0.17 & 0.12 \\
\hline & $\mathrm{CD}(0.05)$ & 325 & 314 & 221 & NS & NS & NS & NS & NS & NS & NS & NS & NS \\
\hline \multirow[t]{2}{*}{$\mathbf{Y} \times \mathbf{S i}$} & S. Em \pm & 111 & 111 & 111 & 0.19 & 0.19 & 0.19 & 0.01 & 0.01 & 0.01 & 0.16 & 0.16 & 0.16 \\
\hline & $\mathrm{CD}(0.05)$ & - & - & NS & - & - & NS & - & - & NS & - & - & NS \\
\hline \multicolumn{14}{|c|}{ Interactions } \\
\hline \multicolumn{2}{|l|}{ N X Si } & NS & NS & NS & $\mathrm{NS}$ & NS & NS & NS & NS & NS & NS & NS & NS \\
\hline \multicolumn{2}{|c|}{ Y X N X Si } & - & - & NS & - & - & NS & - & - & NS & - & - & NS \\
\hline \multicolumn{2}{|l|}{$\mathrm{CV} \%$} & 6.6 & 8.5 & 7.6 & 8.8 & 10.3 & 9.6 & 12.9 & 11.7 & 12.3 & 14.7 & 14.5 & 14.6 \\
\hline
\end{tabular}


Table.3 Effect of nitrogen and silicon on $\mathrm{N}, \mathrm{P}_{2} \mathrm{O}_{5}, \mathrm{~K}_{2} \mathrm{O}$, Silicon and Sulphur contents after harvest of rice under low land conditions (pooled 2 years)

\begin{tabular}{|c|c|c|c|c|c|c|c|c|c|c|c|c|c|c|c|c|}
\hline \multirow{2}{*}{\multicolumn{2}{|c|}{ Treatments }} & \multicolumn{3}{|c|}{ Nitrogen (kg ha $\left.{ }^{-1}\right)$} & \multicolumn{3}{|c|}{$\mathrm{P}_{2} \mathrm{O}_{5}\left(\mathrm{~kg} \mathrm{ha}^{-1}\right)$} & \multicolumn{3}{|c|}{$\mathrm{K}_{2} \mathrm{O}\left(\mathrm{kg} \mathrm{ha}^{-1}\right)$} & \multicolumn{3}{|c|}{ Silicon $\left(\mathrm{kg} \mathrm{ha}^{-1}\right)$} & \multicolumn{3}{|c|}{ Sulphur (mg kg ${ }^{-1}$ ) } \\
\hline & & 2014 & 2015 & Pooled & 2014 & 2015 & Pooled & 2014 & 2015 & Pooled & 2014 & 2015 & Pooled & 2014 & 2015 & Pooled \\
\hline \multicolumn{17}{|c|}{ Nitrogen levels $\left(\mathrm{kg} \mathrm{ha}^{-1}\right)$} \\
\hline \multicolumn{2}{|c|}{ N 0} & 255 & 231 & 243 & 86.4 & 72.8 & 79.6 & 218 & 236 & 227 & 199.6 & 214.7 & 207.2 & 7.14 & 9.80 & 8.47 \\
\hline \multicolumn{2}{|c|}{$\mathbf{N} 75$} & 276 & 262 & 269 & 88.0 & 75.1 & 81.5 & 220 & 238 & 229 & 211.8 & 229.6 & 220.7 & 7.92 & 10.8 & 9.37 \\
\hline \multicolumn{2}{|c|}{ N 100} & 298 & 284 & 291 & 90.1 & 75.1 & 82.6 & 254 & 283 & 268 & 235.1 & 255.5 & 245.3 & 8.15 & 11.7 & 9.93 \\
\hline \multicolumn{2}{|c|}{$\mathbf{N} 125$} & 324 & 308 & 316 & 91.9 & 78.7 & 85.3 & 255 & 290 & 272 & 241.0 & 258.1 & 249.6 & 8.26 & 10.9 & 9.62 \\
\hline \multirow[t]{2}{*}{$\mathbf{N}$} & S. Em \pm & 10 & 8 & 6 & 2.11 & 2.13 & 1.50 & 8 & 7 & 5 & 4.7 & 6.3 & 3.9 & 0.27 & 0.31 & 0.21 \\
\hline & $\begin{array}{l}\text { CD } \\
(0.05)\end{array}$ & 28 & 22 & 17 & NS & NS & NS & 23 & 20 & 15 & 13.5 & 18.3 & 11.1 & 0.79 & 0.88 & 0.58 \\
\hline \multirow{2}{*}{$\begin{array}{c}\mathbf{Y} \mathbf{X} \\
\mathbf{N}\end{array}$} & S. Em \pm & 9 & 9 & 9 & 2.12 & 2.12 & 2.12 & 7 & 7 & 7 & 5.6 & 5.6 & 5.6 & 0.29 & 0.29 & 0.29 \\
\hline & $\begin{array}{l}\text { CD } \\
(0.05)\end{array}$ & - & - & NS & - & - & NS & - & - & NS & - & - & NS & - & - & NS \\
\hline \multicolumn{17}{|c|}{ Silicon levels $\left(\mathrm{kg} \mathrm{ha}^{-1}\right)$} \\
\hline \multicolumn{2}{|c|}{ Si 0} & 258 & 237 & 248 & 81.8 & 64.5 & 73.2 & 194 & 204 & 199 & 162.5 & 169.5 & 166.0 & 6.74 & 8.94 & 7.84 \\
\hline \multicolumn{2}{|c|}{ Si 200} & 280 & 260 & 270 & 85.0 & 68.6 & 76.8 & 234 & 256 & 245 & 231.4 & 250.3 & 240.8 & 7.52 & 10.4 & 8.98 \\
\hline \multicolumn{2}{|c|}{ Si 400} & 294 & 280 & 287 & 94.6 & 83.6 & 89.1 & 252 & 279 & 266 & 242.5 & 263.2 & 252.9 & 8.07 & 11.2 & 9.65 \\
\hline \multicolumn{2}{|c|}{ Si 600} & 320 & 309 & 315 & 95.1 & 84.8 & 89.9 & 267 & 308 & 288 & 251.1 & 275.0 & 263.0 & 9.14 & 12.7 & 10.9 \\
\hline \multirow[t]{2}{*}{ Si } & S. Em \pm & 10 & 8 & 6 & 2.11 & 2.13 & 1.50 & 8 & 7 & 5 & 4.7 & 6.3 & 3.9 & 0.27 & 0.31 & 0.21 \\
\hline & $\begin{array}{l}\text { CD } \\
(0.05)\end{array}$ & 28 & 22 & 17 & 6.1 & 6.2 & 4.2 & 23 & 20 & 15 & 13.5 & 18.3 & 11.1 & 0.79 & 0.88 & 0.58 \\
\hline \multirow{2}{*}{$\begin{array}{c}\mathbf{Y ~ X} \\
\text { Si }\end{array}$} & S. Em \pm & 9 & 9 & 9 & 2.12 & 2.12 & 2.12 & 7 & 7 & 7 & 5.6 & 5.6 & 5.6 & 0.29 & 0.29 & 0.29 \\
\hline & $\begin{array}{l}\text { CD } \\
(0.05)\end{array}$ & - & - & NS & - & - & NS & - & - & NS & - & - & NS & - & - & NS \\
\hline \multicolumn{17}{|c|}{ Interactions } \\
\hline \multicolumn{2}{|c|}{$\overline{\mathbf{N X ~ S i}}$} & NS & Sig & Sig & Sig & NS & Sig & NS & NS & Sig & Sig & Sig & Sig & NS & NS & NS \\
\hline \multicolumn{2}{|c|}{ Y X N X Si } & - & - & NS & - & - & NS & - & - & NS & - & - & NS & - & - & NS \\
\hline \multicolumn{2}{|c|}{ CV \% } & 11.6 & 9.7 & 10.8 & 8.2 & 9.8 & 8.9 & 11.6 & 9.3 & 10.4 & 7.3 & 9.2 & 8.4 & 12.1 & 9.8 & 10.8 \\
\hline
\end{tabular}


Table.4 Interaction effect of $\mathrm{N} x \mathrm{Si}$ on $\mathrm{N}, \mathrm{P}_{2} \mathrm{O}_{5}, \mathrm{~K}_{2} \mathrm{O}$ and Silicon content after harvest of rice (pooled 2 years)

\begin{tabular}{|c|c|c|c|c|c|c|c|c|c|c|c|c|c|c|c|c|}
\hline Treatments & \multicolumn{16}{|c|}{ Nitrogen levels $\left(\mathrm{kg} \mathrm{ha}^{-1}\right)$} \\
\hline Silicon levels & \multicolumn{4}{|c|}{$\mathbf{N}_{\mathbf{0}}$} & \multicolumn{4}{|c|}{$\mathbf{N}_{75}$} & \multicolumn{4}{|c|}{$\mathbf{N}_{100}$} & \multicolumn{4}{|c|}{$\mathbf{N}_{125}$} \\
\hline & $\mathbf{N}$ & $\mathbf{P}_{2} \mathbf{O}_{5}$ & $\mathbf{S i}$ & $\mathbf{K}_{2} \mathbf{O}$ & $\mathbf{N}$ & $\mathbf{P}_{2} \mathbf{O}_{5}$ & $\mathbf{S i}$ & $\mathrm{K}_{2} \mathrm{O}$ & $\mathbf{N}$ & $\mathbf{P}_{2} \mathbf{O}_{5}$ & $\mathbf{S i}$ & $\mathrm{K}_{2} \mathrm{O}$ & $\mathbf{N}$ & $\mathbf{P}_{2} \mathbf{O}_{5}$ & Si & $\mathrm{K}_{2} \mathrm{O}$ \\
\hline $\mathbf{S i}_{0}$ & 226 & 76.0 & 178.5 & 200 & 243 & 75.2 & 169.0 & 193 & 248 & 71.8 & 160.1 & 195 & 274 & 69.7 & 156.3 & 207 \\
\hline $\mathbf{S i}_{200}$ & 243 & 78.5 & 202.7 & 223 & 270 & 79.6 & 219.0 & 224 & 279 & 72.1 & 269.4 & 268 & 287 & 77.0 & 272.3 & 265 \\
\hline $\mathbf{S i}_{400}$ & 248 & 80.3 & 212.7 & 236 & 278 & 85.3 & 240.9 & 243 & 303 & 90.6 & 275.3 & 289 & 318 & 100.2 & 282.6 & 295 \\
\hline $\mathrm{Si}_{600}$ & 254 & 83.6 & 234.9 & 248 & 284 & 86.1 & 254.0 & 258 & 335 & 95.9 & 276.2 & 322 & 386 & 94.3 & 287.0 & 323 \\
\hline & \multicolumn{5}{|c|}{ S. Em \pm} & \multicolumn{3}{|c|}{ CD (0.05) } & \multicolumn{8}{|c|}{$\mathrm{CV} \%$} \\
\hline $\mathbf{N}$ & \multicolumn{5}{|c|}{12} & \multicolumn{3}{|c|}{35} & \multicolumn{8}{|c|}{10.8} \\
\hline $\mathbf{P}_{2} \mathbf{O}_{5}$ & \multicolumn{5}{|c|}{3.0} & \multicolumn{3}{|c|}{8.5} & \multicolumn{8}{|c|}{8.9} \\
\hline $\mathrm{K}_{2} \mathrm{O}$ & \multicolumn{5}{|c|}{11} & \multicolumn{3}{|c|}{30} & \multicolumn{8}{|c|}{10.4} \\
\hline Si & \multicolumn{4}{|c|}{7.9} & & \multicolumn{3}{|c|}{22.3} & \multicolumn{8}{|c|}{8.4} \\
\hline
\end{tabular}


At higher levels of $\mathrm{N} v i z ., 100$ and $125 \mathrm{~kg}$ ha 1 , integration with $\mathrm{Si}$ could regulate the absorption and mobility of $\mathrm{Si}$ in the soil and maintains an optimum level of $\mathrm{Si}$ and hence on one side $\mathrm{N}$ fertilization increases the silicon content in soil (Shivay and Dinesh Kumar, 2009).

Available Si in soil at harvest was influenced significantly by different fertility levels. The data presented in Table 3 showed that effect of silicon on available silicon content was found significant during both the years as well as on a pooled basis. The lowest available silicon content $(162.5,169.5$ and $166.0 \mathrm{~kg}$ $\mathrm{ha}^{-1}$ ) was observed under control during both the years as well as on a pooled basis. The maximum available silicon content (251.1, 275.0 and $263.0 \mathrm{~kg} \mathrm{ha}^{-1}$ ) was recorded due to application of $600 \mathrm{~kg} \mathrm{Si} \mathrm{ha}{ }^{-1}$ during both individual years as well as on a pooled basis. The treatment $600 \mathrm{~kg} \mathrm{Si} \mathrm{ha}$ gave significantly higher available silicon content in soil after harvest of crop over the control and $200 \mathrm{~kg} \mathrm{Si} \mathrm{ha}{ }^{-1}$ during both the years as well as on a pooled basis. However, it was at par with $400 \mathrm{~kg} \mathrm{Si} \mathrm{ha}^{-1}$ during both the years as well as on a pooled basis. The maximum enhancement over control was to the significance of 55, 62 and 58 per cent during both individual years as well as on a pooled basis, respectively. Silicon fertilizers are $\mathrm{Si}$ rich inorganic substance that increases the content of plant available $\mathrm{Si}$ compounds (Monosilicic acids) in the soil. This was attributed to the possibility of sorption and desorption of silicate fertilizes under lowland rice ecosystem. The increased available $\mathrm{Si}$ was anticipated because the added silicate material might have contributed for release of soluble Si. Under submerged conditions, monosilicic acid concentration was increase in the soil solution due to the application of silicate fertilizer and it leads to such a concentration of monosilicic acid in the soil solution to synthesis of poly silicic acids. As a result, the concentration of monosilicic acids falls down due to the effect from silicate fertilizers. Hereafter, an increase in the dose of silicate fertilizers results increasing concentration of monosilicic acids, which is enough to promote both further synthesis of poly silicic acids and an increase in monosilicic acids concentration in the soil solution. Further, it leads to new soil Si status, characterized by a high concentration of both mono and poly silicic acids.

Data presented in Table 4 revealed that combination of highest $\mathrm{N}$ level i.e. $125 \mathrm{~kg} \mathrm{~N}$ ha $^{-1}$ with highest Si level @ $600 \mathrm{~kg} \mathrm{ha}^{-1}$ showed maximum significant $\mathrm{Si}$ content (287.0 $\mathrm{kg} \mathrm{ha}^{-1}$ ) in soil; being at par with $\mathrm{N}$ level $\left(100 \mathrm{~kg} \mathrm{ha}^{-1}\right)$ when coupled with 200 , 400 and $600 \mathrm{~kg} \mathrm{Si} \mathrm{ha}^{-1}$. The lowest Si content in soil after harvest was observed due to 125 $\mathrm{kg} \mathrm{N} \mathrm{ha}{ }^{-1}$ without $\mathrm{Si}\left(160.1 \mathrm{~kg} \mathrm{ha}^{-1}\right)$. Application of $\mathrm{N}$ along with $\mathrm{Si}$ has recorded highest per cent $\mathrm{Si}$ in soil as mentioned above. Silicon fertilizers are $\mathrm{Si}$ rich inorganic substances that increase the content of plant available Si compounds (Monosilicic acids) in the soil. This was attributed to the possibility of sorption and desorption of silicate fertilizes under lowland rice ecosystem of the present study. The increased available $\mathrm{Si}$ was anticipated because of the added silicate material might have contributed for release of soluble Si. These results confirm the earlier findings of Epstein, (1999); Matichenkov et al., (1999) and Savant et al., (1997a).

\section{Available $\mathrm{P}_{2} \mathrm{O}_{5}\left(\mathrm{~kg} \mathrm{ha}^{-1}\right)$}

The effect of different levels of $\mathrm{N}$ on $\mathrm{P}_{2} \mathrm{O}_{5}$ content in soil after harvest of the rice crop was found non-significant during both the years as well as on a pooled basis (Table 3 ). Available $\mathrm{P}_{2} \mathrm{O}_{5}$ in soil at harvest was influenced significantly by different fertility levels. The data presented in Table 3 revealed that effect of silicon on available $\mathrm{P}_{2} \mathrm{O}_{5}$ was 
found significant during both individual years as well as on a pooled basis. The lowest available $\mathrm{P}_{2} \mathrm{O}_{5}$ content $(81.8,64.5$ and $73.2 \mathrm{~kg}$ $\mathrm{ha}^{-1}$ ) was observed under control during both the years as well as on a pooled basis. The maximum available $\mathrm{P}_{2} \mathrm{O}_{5}$ content $(95.1,84.8$ and $89.9 \mathrm{~kg} \mathrm{ha}^{-1}$ ) was recorded due to application of $600 \mathrm{~kg} \mathrm{Si} \mathrm{ha}{ }^{-1}$ during both individual years as well as on a pooled basis. The treatment $600 \mathrm{~kg} \mathrm{Si} \mathrm{ha}{ }^{-1}$ gave a significantly higher available $\mathrm{P}_{2} \mathrm{O}_{5}$ content in soil after harvest of crop over the control and $200 \mathrm{~kg} \mathrm{Si} \mathrm{ha}^{-1}$ during both the years as well as on a pooled basis. However, it was at par with $400 \mathrm{~kg} \mathrm{Si} \mathrm{ha}{ }^{-1}$ during second year and pooled. The maximum enhancement was to the value of 16,31 and 23 per cent during both individual years as well as on a pooled basis respectively, over control. The increased available $\mathrm{P}$ with $\mathrm{Si}$ application could be due to the release of absorbed $\mathrm{P}$ by anion exchange. Due to application $\mathrm{Si}$ compounds and their large surface area, they increase the soil adsorption capacity. These changes in soil optimize the phosphate fertilizer efficiency and due to this transformation of slightly soluble phosphate turn in to plant available forms and reduces the phosphate leaching from the arable horizon. Si fertilizes can also increase the quantity of mobile phosphate in the soil (Gladcova, 1982) and thermodynamic calculations showed that the reaction of displacing phosphate anion by silicate anion from slightly soluble phosphate of the corresponding silicate is possible (Matichenkov and Snyder, 1996).

The interaction effect between $\mathrm{N}$ and $\mathrm{Si}$ was found significant during both the years as well as on a pooled basis. Perusal of data in Table 4 illustrated that interaction effect between $\mathrm{N}$ and $\mathrm{Si}$ application on available $\mathrm{P}_{2} \mathrm{O}_{5}$ content in soil after harvest of crop was found significant. Among all treatment combinations, the highest available $\mathrm{P}_{2} \mathrm{O}_{5}$ content in soil $\left(100.2 \mathrm{~kg} \mathrm{ha}^{-1}\right)$ was observed under combined application of $100 \mathrm{~kg} \mathrm{~N} \mathrm{ha}^{-1}$ and $400 \mathrm{~kg} \mathrm{Si} \mathrm{ha}^{-1}$ on a pooled basis. Application of $\mathrm{N}$ along with $\mathrm{Si}$ has recorded highest per cent $\mathrm{P}_{2} \mathrm{O}_{5}$ in soil as mentioned above. The increase in the available $\mathrm{P}$ content of soil with the application of silicon could be due to utilization of native phosphorus with increasing levels of silicon which resulted in building up of higher soil P status. Si fertilizes can also increase the quantity of mobile phosphate in the soil (Gladcova, 1982) and thermodynamic calculations showed that the reaction of displacing phosphate anion by silicate anion from slightly soluble phosphate of the corresponding silicate is possible (Matichenkov and Snyder, 1996). The model and field experiments have completely confined this suggestion. First, an increase in concentration of monosilicic acids is observed in the soil solution, along with their adsorption on slightly soluble phosphate of calcium, Al, ferric and magnesium, phosphorus was absorbed by applied silicon rich substances. The data demonstrated that adsorbed $\mathrm{P}$ remained in a plant available form (Lindsay, 1979).

\section{Available $\mathrm{K}_{2} \mathrm{O}\left(\mathrm{kg} \mathrm{ha}^{-1}\right)$}

The data presented in Table 3 indicated that effect of nitrogen on available $\mathrm{K}_{2} \mathrm{O}$ content was found significant during both individual years as well as on a pooled basis. The results revealed that application of $125 \mathrm{~kg} \mathrm{~N}^{-1}$ gave the highest available $\mathrm{K}_{2} \mathrm{O}$ content (255, 290 and $272 \mathrm{~kg} \mathrm{ha}^{-1}$ ) during both the years as well as on a pooled basis. The lowest available $\mathrm{K}_{2} \mathrm{O}$ content $(218,236$ and $227 \mathrm{~kg}$ $\mathrm{ha}^{-1}$ ) was observed under control during both the years as well as on a pooled basis. When Si was not applied, increase in level of 0 to $125 \mathrm{~kg} \mathrm{ha}^{-1}$ did not show any significant influence on available $\mathrm{K}$ status of the soil. At 0 to $100 \mathrm{~kg} \mathrm{ha}^{-1}$ level of $\mathrm{N}$, available $\mathrm{K}$ increased due to integration with $\mathrm{Si}$ at 0 to $600 \mathrm{~kg} \mathrm{ha}^{-1} 227,229,268$ and $272 \mathrm{~kg} \mathrm{ha}^{-1}$, 
respectively. These results confirm the earlier findings of Epstein, (1999); Matichenkov et al., (1999) and Savant et al., (1997a).

The data presented in Table 3 revealed that effect of silicon on available $\mathrm{K}_{2} \mathrm{O}$ was found significant during both the years as well as on a pooled basis. The lowest available $\mathrm{K}_{2} \mathrm{O}$ content (194, 204 and $199 \mathrm{~kg} \mathrm{ha}^{-1}$ ) was observed under control during both individual years as well as on a pooled basis. The maximum available $\mathrm{K}_{2} \mathrm{O}$ content in soil after harvest of crop $\left(267,308\right.$ and $288 \mathrm{~kg} \mathrm{ha}^{-1}$ ) was recorded due to application of $600 \mathrm{~kg} \mathrm{Si}$ $\mathrm{ha}^{-1}$ during both individual years as well as on a pooled basis. The treatment $600 \mathrm{~kg} \mathrm{Si} \mathrm{ha}^{-1}$ gave a significantly higher available $\mathrm{K}_{2} \mathrm{O}$ content in soil after harvest of crop over the control and $200 \mathrm{~kg} \mathrm{Si} \mathrm{ha}^{-1}$ during both the years as well as on a pooled basis. However, it was at par with $400 \mathrm{~kg} \mathrm{Si} \mathrm{ha}^{-1}$ during the first year only. The maximum enhancement was to the significance of 38,51 and 45 per cent during both individual years as well as on a pooled basis respectively, over control. Perusal of data in Table 4 illustrated that interaction effect between $\mathrm{N}$ and $\mathrm{Si}$ application on available $\mathrm{K}_{2} \mathrm{O}$ content in soil after harvest of crop was found significant. Among all treatment combinations, the highest available $\mathrm{K}_{2} \mathrm{O}$ content in soil $(323 \mathrm{~kg}$ $\mathrm{ha}^{-1}$ ) was observed under combined application of $125 \mathrm{~kg} \mathrm{~N}^{-1}$ and $600 \mathrm{~kg} \mathrm{Si}$ $\mathrm{ha}^{-1}$ on a pooled basis. Application of $\mathrm{N}$ along with $\mathrm{Si}$ has recorded highest per cent $\mathrm{K}_{2} \mathrm{O}$ in soil as mentioned above. The increase in available $\mathrm{K}_{2} \mathrm{O}$ content of soil with application of silicon could be due to utilization of native $\mathrm{K}_{2} \mathrm{O}$ with increasing levels of silicon which resulted in building up of higher soil $\mathrm{K}_{2} \mathrm{O}$ status. The increased available $\mathrm{K}$ with $\mathrm{Si}$ application could be ascribed to the alterations in crystal structures of clay lattices which might have related in a reduction in $\mathrm{K}$ fixation thus releasing potassium. The increased available $\mathrm{K}$ with $\mathrm{Si}$ application could be ascribed to the alterations in crystal structures of clay lattices which might have related in a reduction in $\mathrm{K}$ fixation thus releasing potassium. The results are in conformity with the findings of Matichenkov (2007); Epstein, (1999); Matichenkov et al., (1999) and Savant et al., (1997a).

\section{Available sulphur (mg kg $\left.{ }^{-1}\right)$}

The data presented in Table 3 indicated that varying levels of $\mathrm{N}$ significantly influenced the available sulphur in soil after harvest of rice. The maximum available $S$ content in soil (11.72 and $9.93 \mathrm{mg} \mathrm{kg}^{-1}$ ) was recorded due to application of $100 \mathrm{~kg} \mathrm{~N}^{-1}$ during second years and pooled, but in case of first year it was maximum value $\left(8.26 \mathrm{mg} \mathrm{kg}^{-1}\right)$ with the application of $125 \mathrm{~kg} \mathrm{~N}^{-1}$. The treatment $100 \mathrm{~kg} \mathrm{~N} \mathrm{ha}{ }^{-1}$ gave significantly higher available sulphur content in soil after harvest of crop over the control during second year as well as on a pooled basis. Application of $\mathrm{Si}$ significantly increased the available $\mathrm{S}$ content in soil Table 3 during both individual years as well as on a pooled basis. The maximum available $\mathrm{S}$ content in soil after harvest of crop $\left(9.14,12.72\right.$ and $10.93 \mathrm{mg} \mathrm{kg}^{-1}$ ) was recorded due to application of $600 \mathrm{~kg} \mathrm{Si} \mathrm{ha}^{-1}$ during both individual years as well as on a pooled basis. The treatment $600 \mathrm{~kg} \mathrm{Si} \mathrm{ha}{ }^{-1}$ gave a significantly higher available $S$ content in soil after harvest of crop over the control, 200 and $400 \mathrm{~kg} \mathrm{Si} \mathrm{ha}^{-1}$ during both the years as well as on a pooled basis. The maximum enhancement was to the significance of 36,42 and 39 per cent during both individual years as well as on a pooled basis respectively, over control. Available sulphur in soil after harvest of crop was significantly increased by silicon fertilization. The calcareousness and high clay content also contribute to more adsorption of sulphur on exchangeable complexes and sulphates in soils are retained more than one mechanism. The low mobility of sulphur in soil and the soil conditions conducive for 
adsorption might have resulted in residual availability of sulphur in soil after harvest of the crop. The results are in conformity with the findings of Epstein (1999); Matichenkov et al., (1999) and Savant et al., (1997a). The interaction effect of $\mathrm{N} \times \mathrm{Si}$ on sulphur content in soil after harvest of the crop was found non-significant during both the years as well as on a pooled basis.

\section{References}

Bijay, S., Gupta. S. and Yadvinder, S. 2006. Need-based nitrogen management using leaf color chart in wet direct-seeded rice in north-western India. Journal of New Seeds 8(1), 35-45.

Chen, J.X., Tu, N.M., Yi, Z.X. and Zhu, H.L. 2011. Effect of Silicon Fertilizer on Nitrogen Utilization Efficiency of Super Early Rice. Cereal Crop Research.

Dehal, P. and Mishra, G. 1994. Interaction of spacing and nitrogen in rice. Oryza 31(2), 149-150.

Epstein, E. 1999. Silicon. Annual Review of Plant Physiology and Plant Molecular Biology 50, 641-644.

Gladcova, K.F. 1982. The role of silicon in phosphate plant nutrition. Agrochemistry, 2, 133.

Inanaga, S., Higues, Y. and Naoya, C. 2002. Effect of silicon application on reproductive growth of rice plant. Soil Science and Plant Nutrition 48, 341347.

Jackson, M. L. 1973. Soil chemical analysis. Prentice Hall of India Pvt. Ltd. New Delhi.

Korndorfer, G.H., Coelho, M.N., Snyder, G.H. and Mizutani, C.T. 1999. An evaluation of soil extractants for silicon availability in upland rice. Journal of Plant Nutrition 23, 101-106.

Korndorfer, G.H., Snyder, G.H., Ulloa, M. and Datnoff, L.E. 2001. Calibration of soil and plant silicon for rice production. Journal of Plant Nutrition 24, 1071-1084.

Lindsay, W.L. 1979. Chemical equilibria in soils. John Wiley \& Sons, New York. 449.

Ma, J. F., Tamai, K., Yamaji, N., Mitani, N., Konishi, S., Katsuhara, M., Ishiguro, M., Murata, Y., \& Yano, M. 2006. A silicon transporter in rice. Nature, 440, 688-691.

Ma, J.F. and Takahashi, E. 1990. Effect of silicate on phosphate availability of rice in a P deficient soil. Plant Soil 133, 151-155.

Mahajan, K.K. and Tripathi, B.R 1992. Effect of increasing levels of different Urea based fertilizers on yield and nitrogen nutrition of rice in an alfisal. Oryza 29(2), 101-106.

Malidareh, G.A., Kashani, A., Nourrnohammadi, H.R., Mobasser. and Atavi, V. 2009. Effect of silicon application and nitrogen rates on $\mathrm{N}$ and $\mathrm{Si}$ content and yield of rice (Oryza sativa L., ) in two water systems in north of Iran. World Applied Sciences Journal 6(6), 719-727.

Matichenkov, V., Bovharinikova, E.A., Calvert, D.V. and Snyder, G.H. 2000. Comparative study of soil status in sandy soils of South Florida. Soil and crop science 59, 132-137.

Matichenkov, V.V. and Snyder, G.H. 1996. The mobile silicon compounds in some South Florida soils. Eurasian Soil Science 12, 1165-1173.

Matichenkov, V.V., Calvert, D.V. and Snyder. G.H. 1999. Silicon fertilizers for citrus in Florida. Proceedings of the Florida State Horticultural Society 112, 5-8.

Mauad, M., Crusciol, C.A.C., Grassi Filho, H. and Correa. J.C. 2003. Nitrogen and silicon fertilization of upland rice. Scientia Agricola 60, 761-765.

Muir, S., Khoo, C. and McCabe, 2001. Some 
effects of silicon in mixes on growth and protection of plants against fungal diseases. In L.E. Datnoff, G.H. Snyder and G.H. Komdorfer, (eds.) - Silicon in Agriculture. Elsevier Science B.V, Amsterdam, The Netherlands, 374.

Munir, M., Carlos, A.C.C., Hello, G.F and Juliano, C.C. 2003. Nitrogen and silicon fertilization of upland rice. Scientia Agricola 60, 1-10.

Nayar, P.K., Misra, A.K. and Patnaik, S. 1982. Silica in rice (Oryza saliva L) and flooded rice soils: Effects of flooding on the extractable silica in soils and its relation with uptake by rice. Oryza 19 , 34-42.

Olsen, S.R., Cole, C.V., Watanabe, F.S. and Dean, L.A. 1954. Estimation of available phosphorus in soils by extraction with sodium bicarbonate. Circulation from USDA. 939.

Piper, C.S. 1966. Soil and Plant Analysis. Hans Publishers, Bombay. 137-153.

Ponnamperuna, F.N. 1972. The chemistry of submerged soils. Advances in Agronomy 24, 29-96.

Prakash, N.B. 2002. Status and utilization of silicon in Indian rice farming. In Proceedings 1111 of Second Silicon in Agriculture.

Savant, N.K., Datnoff, L.E. and Snyder, G.H. 1997. Depletion of plant available silicon in soils: a possible cause of declining rice yields. Communication in Soil Science and Plant Analysis 28, 1245-1252.

Savant, N.K., Datnoff, L.E. and Snyder, G.H. 1997a. Depletion of plant available silicon in soils: a possible cause of declining rice yields. Communication in Soil Science and Plant Analysis 28, 1245-1252.

Shivay, Y.S. and Dinesh, K. 2009. Importance and management of silicon deficiency in rice. Indian Farming 3436.

Singh, K., Singh, Y., Singh C.S., Singh, R., Singh, K.K. and Singh, A.K. 2002. Silicon nutrition in paddy. Fertilizer news 50(2), 41-48.

Snyder, G.H., Jones, D.B. and Gascho, G.J. 1986. Silicon fertilization of rice on Everglades Histosols. Soil Science Society of America Journal 50, 12591263.

Subbaiah, B.V. and Asija, G.L. 1956. A rapid procedure for the determination of available nitrogen-in soils. Current Science 25, 259-260.

Sudhakar, P.C., Singh, J.P., Yogeshwar S. and Raghavendra S. 2006. Effects of graded levels and silicon sources on crop yield, uptake and nutrient use efficiency in rice. Indian Journal of Agronomy 51(3), 186-188.

Walkley, A. and Black, C.A. 1934. Estimation of organic carbon by chromic acid titration method. Soil Science 37, 29-38.

Williams, C.H. and Steinbergs, A. 1959. Soil sulphur fractions as chemical indices of available sulphur in some Australian soils. Australian Journal of Agricultural Research 10, 340-352.

\section{How to cite this article:}

Malav, J.K., V.P. Ramani, J.K. Patel, R.P. Pavaya, B.B. Patel, I.M. Patel and Patel, V.R. 2018. Rice Yield and Available Nutrients Status of Loamy Sand Soil as Influenced by Different Levels of Silicon and Nitrogen. Int.J.Curr.Microbiol.App.Sci. 7(02): 619-632. doi: https://doi.org/10.20546/ijcmas.2018.702.077 